\title{
GCU
}

Glasgow Caledonian

University

University for the Common Good

\section{The playground of the rich? Growing social business in the 21st Century}

Steiner, Artur; Teasdale, Simon

Published in:

Social Enterprise Journal

DOI:

10.1108/SEJ-12-2015-0036

Publication date:

2016

Document Version

Author accepted manuscript

Link to publication in ResearchOnline

Citation for published version (Harvard):

Steiner, A \& Teasdale, S 2016, 'The playground of the rich? Growing social business in the 21st Century', Social Enterprise Journal, vol. 12, no. 2, pp. 201-216. https://doi.org/10.1108/SEJ-12-2015-0036

\section{General rights}

Copyright and moral rights for the publications made accessible in the public portal are retained by the authors and/or other copyright owners and it is a condition of accessing publications that users recognise and abide by the legal requirements associated with these rights.

Take down policy

If you believe that this document breaches copyright please view our takedown policy at https://edshare.gcu.ac.uk/id/eprint/5179 for details of how to contact us. 


\title{
The Playground of the Rich? Growing Social Business in the $21^{\text {st }}$ Century
}

\begin{abstract}
Purpose: This article aims to explore how nascent social businesses move beyond the incubation phase and it develops understanding of how early stage social businesses access finance to achieve growth.
\end{abstract}

Design/methodology/approach: This exploratory and inductive study is based on four focus group discussions with early- stage social entrepreneurs, 'successful' social entrepreneurs who had achieved growth, and social impact investors.

Findings: Social capital allows a social business founder to access financial capital to 'prove their concept', or to directly attract investment from family and friends for start-up costs. In order to gain funding, social entrepreneurs present the desired image of the heroic changemaker. Interestingly, creating the right impression is equally important in securing financial capital as the 'hard-work' itself.

Research limitations/implications: Our study was conducted in London which, like many other 'global' cities, has a unique business environment. The study is exploratory in nature. Further work in this area is required to draw more definitive conclusions.

Practical implications: Financial products offered to social businesses are often dispersed and inappropriate. The study indicates that access to 'soft loans' and grants is critical in the early-stages of social business growth and that social entrepreneurs use both formal and informal funding sources to develop their businesses. Where a person is not connected to wealthy acquaintances either through family, or through social networks, they may often struggle to access finance in a world where the network's resources appear to be as important as the entrepreneur's resourcefulness. This has particular implications for the demographic make-up of 'successful social entrepreneurs' operating social businesses as these may be drawn from the most privileged and / or well-connected members of a group which already appears skewed towards white middle class males.

Social implications: Our study highlights that current support structures favours relatively privileged social entrepreneurs rather than encompassing and empowering those disadvantaged, social minority groups and those in the greatest need. This is important 
because social business is often portrayed, possibly incorrectly, as a mechanism for addressing poverty through empowerment of disadvantaged groups.

Originality/value: Research in social business development has largely neglected the social and cultural dynamics that embed start-ups. We tackle this gap and contribute to building knowledge in the area of early-stage social business development.

Keywords: Social business, Hubs, business growth, finance, social entrepreneurs, social investors.

\section{INTRODUCTION}

As the social enterprise field matures we can begin to see more and more crossover with 'mainstream' business. Large for-profit companies have adopted many of the ideas initially developed by social entrepreneurs. Sustainable business discourses and the so called 'triple bottom line' have become common parlance. Within academia a popular response to financial crises of the early $21^{\text {st }}$ Century is that businesses need to create shared value in order that communities and shareholders can benefit over the longer term (Porter and Kramer, 2011). This transfer of ideas between social enterprise and mainstream business operates in both directions. In the United Kingdom the social enterprise concept, which emerged from a radical cooperative tradition, has been stretched over time to also incorporate what Teasdale (2012a) labels social businesses - organisations that have an explicit social purpose but which have no constraints on ownership, assets or the payments of dividends to shareholders. Relatedly, Innovation Hubs - entrepreneurial spaces for business incubation and acceleration that are designed to facilitate innovation (Toivonen and Friederici, 2015) - have been adapted for use in the social enterprise sphere (Bachmann, 2014).

There is some understanding in the academic literature of the requirements of early stage social enterprises (Yunus et al., 2010) and of how early stage social entrepreneurs might access financial capital (Teasdale, 2010). Nonetheless relatively little attention has been paid to how social entrepreneurs grow their ventures (Hynes, 2009; Lyon and Fernandez, 2012) with some highlighting more general issues associated with accessing finance (Sunley and Pinch, 2012), and others showing usefulness of the concept of bricolage that denotes resourcefulness and adaptability based on recombining available resources for new purposes and innovation, and achieving goals with whatever is at hand (Di Domenico et al. 2010, 
Levi-Strauss, 1966). In recent years the Hub movement has increasingly served as a vehicle for social entrepreneurs to grow their nascent social businesses beyond the incubation phase. Indeed the motivation for this article arose from speaking to senior management at the Impact Hub Kings Cross (The Hub) - a shared workspace and accelerator for social businesses. Their experience had taught them that social business start-ups often grow in sudden bursts, straining the capacity of the founding team. For instance, in the early-stage of social business development, social entrepreneurs must simultaneously deliver their products and services, increase logistical efficiencies, manage administration tasks such as accounting, develop new markets and products, and manage the growth momentum. Similarly to Small and Medium Enterprise (SME) owners, they have to possess a range of skills and deal with purchasing, production, sales, distribution, finance and other broad roles (Steiner and Cleary, 2014; Steinerowska-Streb and Steiner, 2014).

According to Hub managers, many social entrepreneurs are unable to meet these competing demands and risk failure. Ironically, this failure may arise not because there is no demand for their products and services but as a consequence of being unable to meet the additional demands caused by their success. This article thus seeks to better understand how early stage social businesses access finance to achieve growth.

We begin by providing a necessarily brief overview of Hubs, Social Businesses and the challenges faced in moving from incubation to acceleration. Next we set out our research design involving a series of focus groups with Hub members including those running early stage social businesses, 'successful' social entrepreneurs who had achieved growth, and social impact investors. Our findings sections highlights that access to different forms of finance is perceived as important to facilitate growth. However this access to finance is uneven, and, on the surface at least, appears to be open to those with 'drive and talent'. Notwithstanding the fact that working long hours for little reward is an engrained aspect of socially entrepreneurial culture (Dempsey and Sanders, 2010), we suggest that this reflects a need for successful entrepreneurs to be able to narrate entrepreneurial stories (Lounsbury and Glynn, 2001) which accentuate drive and commitment to make up for the lack of a track record. For other social entrepreneurs, being embedded in resource-rich social networks indirectly provided access to finance, or helped them negotiate the array of potential funders. However not all social entrepreneurs are able to commit to working long hours, possess the ability to narrate entrepreneurial stories, or to rely upon such dense financially rewarding, networks. Taken together our findings suggest that 'successful' social entrepreneurs are likely 
to be drawn from relatively privileged socio-economic groups. In the concluding sections we discuss how Hubs and policymakers might seek to widen the field of social business beyond the 'playground of the rich', and set out areas for future research.

\section{Hubs}

The Hubs concept apparently emerged as many social innovators seemingly worked in isolation without access to experience, infrastructure and networks needed to transform their ideas into reality. Hubs claim to offer a thinking space that promotes spirit of grassroots entrepreneurship and innovation, and where people collaborate and blend their interests and aspirations and, as such, boost their creativity and enhance their venture concepts. As opposed to formal and stifled office environments, Hubs allow for flexible co-working, semiopen meeting rooms, workshop spaces, a secluded library for quiet thinking as well as a kitchen area where participants can meet over lunch or coffee. Users of Hubs have no assigned workstations and, therefore, they sit next to a different person every time they visit the hub. This approach enhances the cross-fertilisation of ideas. According to Toivonen and Friederici (2015), this specific Hub environment leads to 'creative clashes' between people from different networks and domains, and where heterogeneous cognitive resources facilitate novel combinations of ideas and practices. In addition, Hubs organise community-orientated events including business lunches, business clinics, and skill-sharing sessions as well as online communication revealing a hub's existence to a broader audience. As such, Hubs are perceived as a mixture of business incubators, a learning lab, and a professional membership community. Members pay a fee to use this creative space, and have access to the multiple benefits they offer. After more than a decade of their existence, Hubs are perceived partially as a movement, partly a business and partly a network (Bachmann, 2014), and sometimes are perceived to create a type of sub-culture in the context of local societies. However, and despite positive opinions about the Hubs, some researchers indicate that it is difficult to capture the precise features defining Hubs. Also, an assessment of whether Hubs work well as an entrepreneurship intermediary can be challenging. Consequently, it is recommended to conduct more research enabling to grasp and evaluate the strengths and limitations of the Hubs (Toivonen and Friederici, 2015).

\section{Social business}


In this article we use the term "social business" ${ }^{1}$ to refer to organisations which adopt a mainstream business legal from but also have an explicit social purpose. Teasdale (2012a) uses the term with reference to social enterprise to distinguish 'for-profit organisations operating in and around the social sector providing public or social goods' (102), and identified a growing social business discourse in England in the early years of the $21^{\text {st }}$ century whereby organisational form was seen as irrelevant and some parts of the social enterprise 'movement' celebrated the creation of private profit from public good. Wilson and Post (2013) conceptualise social business as a hybrid organisational group that exists where

"an emerging social innovation is also seen as a viable business opportunity and turned into a commercial for-profit business creating, in the process, new market space while also simultaneously attaining a social objective" (Hockerts, 2006:145).

Hockerts (2006) uses Whole Foods Market and the Body Shop as examples of social businesses, and positions them conceptually between for-profit businesses and mission driven organisations.

Social businesses then are similar to social enterprises in that they have an explicit social mission, but, like mainstream businesses, exist to create profits for owners and shareholders. In the United Kingdom it is has been estimated that there were around 55,000 for-profit social businesses in 2007 (Teasdale et al., 2013). As Vickers and Lyon (2014) note, little is known about this particular form of organisational hybrid, particularly as regards their emergence and early stage growth.

\section{From incubation to acceleration}

The process of venture creation in the private sector has been heavily researched and often modelled. In relation to entrepreneurship, Granter (1985) recognises that new venture creation is an outcome of the nexus of individualism, environment and processes. These processes are complex and depend on many factors including entrepreneurs themselves, the environments in which they operate and the type of enterprise they wish to create. A new venture is created only when an entrepreneur is successful in mobilising sufficient resources in response to a perceived need and opportunity (Aldrich, 1995). Access to resources is

\footnotetext{
${ }^{1}$ It should be noted that Yunus et al. (2010) use the term social business in almost the opposite sense to distinguish his own particular model of non-dividend company from social enterprises. While Yunus's conceptualisation has taken hold in some parts of the world, in Europe and North America the more common approach is to use social business in the same way we do here.
} 
essential in creating and developing a new venture. As such, it is significant to recognise how social businesses mobilise pools of resources to start new business and develop it.

In general, organisations develop around sequential stages including pre-venture, start-up, growth, and maturity (Haugh, 2007). To access resources, nascent entrepreneurs devote their time to the business and engage in numerous pre-venture activities such as seeking and gaining financial support and/or organising a team (Carter et al., 1996). During this planning stage, people, ideas and resources are in the process of being brought together. Frequently, the resource acquisition and network creation precede formal venture creation. For instance, networks are important in contributing resources to the new venture. The importance of networks is not limited only to the pre-venture stage and previous studies have shown that a formal support network and a tailor-made support network assist new ventures in progression through all development stages. Consequently, networks are perceived to be an indigenous element in new venture creation (Haugh, 2007).

The pre-venture stages of venture creation are often hidden, inadequately resourced, and reliant on 'sweat equity'. Drawing on the concept of bricolage (Di Domenico et al., 2010), some entrepreneurs - bricoleurs - accomplish their goals with little or seemingly no resources at all, and thus, it is a useful approach for new organisations or organisations in new industries (Baker and Nelson 2005). Importantly, and as documented in previous research, the act of creating a new venture is socially embedded. Social networks and relations of business creators are central to the entrepreneurial process as they provide the context through which the venture gains additional resources (Jack and Anderson, 2002). For instance, Lounsbury and Glynn (2001) indicate that entrepreneurial stories facilitate the crafting of a new venture identity, developing business legitimacy and creating competitive advantage. The entrepreneurial stories are especially important in the early stages of business creation. This is because many newly created ventures lack proven track records. Stories can promote, explain and rationalise a new business and, therefore, reduce perceived uncertainty associated with the entrepreneurial process. Consequently, successful stories can help in legitimising, attracting potential investors and, as a result, in acquiring financial capital and accessing new resources. However, first-time entrepreneurs might find it challenging to refer to a history of proven success. As such, featuring prominent social connections associated with 'borrowing reputation' is another important way in which entrepreneurs go about achieving legitimacy and subsequent access to resources.

As opposed to commercial businesses that most frequently have well-developed business plans assessed against their financial viability, social businesses aim to tackle social 
challenges and use enterprise activities to simultaneously generate income and create social value. It would appear likely that, ceteris paribus, social businesses generate less profit than commercial businesses due to their internalisation of social costs (Doherty et al., 2014). This may make it more difficult to access finance as most mainstream lenders do not take the social value created into account. As such, it could be argued that social businesses face more adversities than commercial ventures. However, it may be that social investors who choose to invest in companies that are actively creating positive social or environmental impacts can act as supporters to social business development (Nicholls, 2010). There are comparatively few studies examining how early-stage social businesses access resources. However, a theme which consistently emerges from the wider social enterprise literature is that social entrepreneurs utilise strong relational ties with stakeholders to access resources (Dacin et al., 2010) and build external legitimacy (Doherty et al., 2014). In combining commercial and prosocial logics, social businesses may draw upon different elements of their hybrid identity (or identities) to present different stories individually tailored to specific funders (Teasdale, 2010a). To some extent then, it would seem that the network environment of Hubs can provide an ideal seed-bed for social businesses to build relational ties with internal and external stakeholders in order to attract funding to help grow their businesses.

\section{METHODOLOGY}

\section{Research design}

This exploratory and inductive study aimed to identify how early stage social businesses located in Hubs might access finance to achieve growth. Because the study's objective was exploratory in nature, with a particular focus on the perceptions of social entrepreneurs and social investors, we developed a qualitative approach drawing primarily on focus groups to gather data.

Focus groups represent one-off meetings of people brought together to discuss and interact around a specific topic (Longhurst, 2003). Group dynamics can stimulate dialogue and allow a variety of views to emerge (Stewart et al., 2007). Focus groups which bring together participants from different perspectives may lead to informative discussions and can reveal unexpected findings that extend one person's opinion (Bedford and Burgess, 2001). In addition, focus group dialogues can show how opinions are formed and they provide an insight into social contexts as well as understanding about how stakeholders understand 
particular issues (McNeill and Chapman, 2005). All these aspects were relevant and important in this study.

Despite the strengths of focus groups, particular limitation is that the opinions of participants might not be representative as people with strong personalities may dominate a discussion, influencing its final outcome (McNeill and Chapman, 2005). There is also a danger of 'group think' where the views of the majority suppress other individual opinions, or when group members become uncritical of shared discussion points. Focus groups also face a challenge of 'cultural alignment' where people express views that they feel will be acceptable to other members (Janis, 1982; Morgan, 2002). In order to address these issues, the focus group facilitators aimed to ensure that all participants could contribute equally revealing their opinions. By running four separate focus groups addressing the same themes we hoped to further reduce this potential for bias. Also, the focus groups were heterogeneous and led to good cross-stakeholder group discussions. Different stakeholders, possessing varying experiences and opinions, developed diverse lines of arguments, and exciting conversations and interactions amongst participants followed. The themes developed from the data do support and add to the findings of other related studies.

\section{Sampling and data collection}

Our sample frame consisted of social business experts including those running early stage social businesses, 'successful' social entrepreneurs ${ }^{2}$, and social impact investors based in London, England ${ }^{3}$. These groups were important as they are directly influenced by, or they directly influence support structures associated with early-stage staff employment or financial mechanisms available to social businesses. Social entrepreneurs were drawn primarily from members of the Hub network, although to ensure broader perspective 'successful' social entrepreneurs from outside of the network, who had successfully negotiated the initial growth stage, were also invited to participate. Social business experts were randomly selected from the Hub contact list, and by inviting further experts drawn from those attending an international social business conference held in Oxford, England. All participants were contacted four weeks prior to the intended date of the focus group, and were informed of the aims of the study.

\footnotetext{
${ }^{2}$ In this study, 'successful' social entrepreneurs were classified as those who 'scaled' and achieved growth in their employment.

${ }^{3}$ London, like many other 'global' cities has particular unique circumstances that mean that our findings cannot be readily generalised to other cities, where, for example, the challenges facing social entrepreneurs may be very different.
} 
A total of four focus groups were held between March and June 2015. The first two focus groups (of seven and nine people) contained a mix of early-stage social entrepreneurs from the Hub network and 'successful' social entrepreneurs from outside of the network. The third and fourth focus groups (of twenty and ten people) consisted of mixed social business experts including early-stage social entrepreneurs, 'successful' social entrepreneurs, and social impact investors from a variety of funds and offering a variety of investment products. The latter group of discussants arrived from across the United Kingdom, although most were located in London. These four focus groups aimed to explore issues that social entrepreneurs face in the early-stages of growth, with particular emphases on securing funding, and recruiting their first employees. A broad topic guide was developed based on the initial suppositions of the Hub team (which were outlined in the introduction to this article).

\section{Data analysis}

All focus group participants were presented with the same core questions. The focus groups were digitally recorded, with the permission of all participants. Recordings were fully transcribed verbatim. Focus group participants were ensured anonymity in research outputs (Wiles et al., 2006). In addition, researchers' field notes were collated and their observations recorded. All transcripts were read by the lead researcher and, independently, by two other researchers. Although the Hub managers knowledge of the subject area, and the researchers (initially limited) knowledge of the academic literature enabled the construction of a schedule for data collection, the exact categories describing the theme under investigation emerged during data analysis. Emerging themes were discussed and consensus reached on an initial coding schedule which was used as a basis for systematic analysis of transcripts. Hence, all data were coded, categorised and analysed using the constant comparison method. This involved initially manually trawling transcripts for themes, but abductively weaving backwards and forwards between data and academic literature (Pierce, 1932; Dey and Teasdale, 2013). The constant comparative method also involved breaking down the data into discrete 'incidents' (Glaser and Strauss, 1967) or 'units' (Lincoln and Guba, 1985) and coding them to categories. Categories arising from this method helped to identify themes significant to the project's focus-of-inquiry and lead to both descriptive and explanatory categories (Lincoln and Guba, 1985). Emerging categories underwent content changes as units and incidents were compared and categorised, and as understandings of the properties of categories and the relationships between categories were developed and refined over the course of the analytical process. As Taylor and Bogdan (1984, p.126) summarise: 'in the 
constant comparative method the researcher simultaneously codes and analyses data in order to develop concepts; by continually comparing specific incidents in the data, the researcher refines these concepts, identifies their properties, explores their relationships to one another, and integrates them into a coherent explanatory model'. Hence, the themes presented in the findings (including (i) access to financial capital, (ii) drive and talent and (iii) access to social networks) were not pre-determinate but emerged from the data when they were analysed. This approach elicited detailed information about existing finance mechanisms that could support social businesses in hiring their first employees and early-stage business growth.

\section{FINDINGS}

Our inductive approach to analysis necessitated weaving backwards and forwards between emergent findings and academic literature to help make sense of our data. Hence this section also refers to supporting (or otherwise) academic literature where relevant. First we show that participants in our study highlighted that access to appropriate finance was a major issue influencing the growth of early-stage social businesses. However, access to finance was uneven amongst participants. Two themes in particular arose from the data that help explaining this uneven access. First, the attention paid by investors to the 'drive and talent' of the social entrepreneur and, second, the importance of social networks in linking social entrepreneurs to finance. While these themes are unsurprising to those familiar with mainstream entrepreneurship, our study also highlighted that uneven access to financial capital may be associated with gender and social class. The implications of this for a 'sector' that prides itself on driving social change and addressing poverty and exclusion are developed in our concluding section.

\section{Access to appropriate financial capital}

Unsurprisingly, a lack of access to appropriate financial resources was seen as by Hub members as a key barrier to moving beyond the incubation stage. Hub members reflected upon the challenges in accessing financial support: "we need capital, but we are too early for investment - angels and social investors say it is too soon." Rather than lack of financial availability, the main problem encountered by social entrepreneurs is the cost of borrowing money. The loans that were generally available to hub members were seen as short term, risky and expensive.

'Successful' social entrepreneurs also recalled their early struggles accessing financing. Many social entrepreneurs highlighted that lack of suitable funding reduced 
growth potential of their ventures. One social entrepreneur had avoided loans during the formative years of their social business. When asked if loans might have helped the business grow quicker the social entrepreneur replied: "Yes, but the terms would have been unfavourable." As another social entrepreneur explained, the high interest rates had an adverse impact on financial performance: "It affects cash-flow and profitability."

Put simply, the hub members in our study were not able to afford the repayments of commercial loans. Frequently, they perceived commercial loans as being too risky and not suitable for social businesses. There is clearly a gap between what hub members are able/prepared to pay for capital and the terms at which social investors are able to lend money. Hub members felt that intermediaries and social investors should take more of the financial risk burden, as one explained:

"The real question is: who will take the risk?...it should be [government-funded social investor working with social businesses]. Give social entrepreneurs more cash to allow swift, talent-attracting growth."

When discussing financial options supporting business growth, hub members expressed a clear preference for "soft loans with no interest or no immediate repayment schedule." This type of funding was also appreciated by 'successful' social entrepreneurs: "at the beginning we had soft loans...it was amazing and meant we could build a customer base."

While agreeing that access to affordable finance was problematic, many of the 'successful' social entrepreneurs had been able to negotiate this. One 'successful' social entrepreneur remarked: "The finance is out there, [but] there is a wider communication problem in the sector." This point was reinforced by social investors in our study, who claimed that there are a number of funding streams supporting social entrepreneurs and their ventures. To some extent, therefore, the problem may be that social entrepreneurs are not able to find out about funding opportunities that exist.

Interestingly, our study shows that some 'successful' social entrepreneurs not only know how to negotiate the social finance landscape, but also, how to creatively interpret the rules of the various financial products. Many financial products are limited to particular types of projects, and may be linked to specific timeframes and/or outputs. Interestingly, these rules can be creatively interpreted (see Scott and Teasdale, 2012). As one 'successful' social entrepreneur described, "some funders say they don't fund salaries - but I need the team to grow the impact, or business, so I end up creating an elaborate scheme which is actually hiding salaries." 
Other 'successful' social entrepreneurs were able to access financial support from family members. As one explained: "the bank of dad has helped us out a few times." While 'soft loans' from friends and family can be helpful for some social entrepreneurs, they are not without their own problems. Another 'successful' social entrepreneur explained how it is less acceptable to take risks using money borrowed from family members:

“borrowing low risk, friendly money from family meant we didn't want to borrow any more than we absolutely had from them - which has meant we have had to go slowly."

Moreover, soft loans from friends and family may not be an option for social entrepreneurs who do not have wealthy friends and family. However, 'successful' social entrepreneurs from less privileged backgrounds had often proved more creative in their use of resources. For example, one social entrepreneur described the importance of state benefits while leading the company through the start-up phase: "I lived on benefits while setting up my first business." This confirms Di Domenico et al. (2010, p. 699) point indicating that "the lack of resources pushes the social entrepreneurs to use all available means to acquire unused or underused resources that are capable of being leveraged in a different way to create social value". Clearly, these more 'creative' approaches might not be viable options for all social entrepreneurs and cannot be captured in, or supported by, social business development strategies and emerging policies.

\section{Drive and talent}

Academic literature indicates that in order to succeed many social entrepreneurs sacrifice their personal life (Dempsey and Sanders, 2010). Hub members and 'successful social entrepreneurs' stressed that social business development requires commitment, personal dedication and sacrifice from the founders: "On a personal level you need to be able to take a significant hit - emotional and financial - to grow." This point appears to confirms results of other studies indicating that social entrepreneurs are ready to work long hours without receiving high personal financial gain (Steinerowski et al., 2008) pursuing career paths that are at odds with a capitalist model based on the maximisation of profit, higher salary and benefits. Instead the 'reward' for participants in our study was more akin to the feeling that social entrepreneurship is more meaningful, inspiring and fulfilling. But as Dempsey and Sanders (2010) note, this altruism and self-sacrifice can result in an unhealthy work / life balance. 
Social investors, in the main, agreed that drive and commitment are necessary attributes for social business development, while also highlighting the need for personal sacrifice. As one investor put it:

"The entrepreneur has to be able to attract resources. It's the deeper question: How long, for example, can the entrepreneur not pay him/herself at all and prioritise employees?"

There is a tendency, therefore, to illustrate social entrepreneurs as 'superhuman' and 'superheroes' characterised by their 'can do' approach. This strongly relates to the Schumpeterian picture of entrepreneurs that presents them as 'men of action' (sic) motivated by a desire to 'demonstrate to the world their success' (Schumpeter, 1934). Social entrepreneurs have to assess the cost associated with their work/life balance with some of them not willing to jeopardise personal relationships, health and wellbeing that frequently is (or perceived to be) required to develop a successful social business (Dempsey and Sanders, 2010). Interestingly one investor felt that the personal sacrifice necessary to develop a social business and raise funding was a useful process in that it filtered out those unsuitable for investment, highlighting that "the right entrepreneurs will overcome the initial financial issues [because] there is always a way."

Understandably not all Hub members were keen to make such personal sacrifices in order to achieve growth, although they were reluctant to say this within the environment of the focus groups. For many aspiring social entrepreneurs the discourse around drive and talent (with the emphasis seemingly on drive rather than talent). However it is important to recognise that while long hours and self-sacrifice might well be the norm, what was of key importance is for social entrepreneurs to be able to articulate to customers and investors the 'drive and talent' to grow a business, ensure scaling success and business survival. Discussions in one of the focus groups suggested that customers and investors were buying into the social entrepreneur as much as the social business or product. Thus 'success' requires the ability to present the desired image of the heroic change-maker in order to attract funding. To some extent this links back to the literature on storytelling discussed previously. If an investor perceives that a social entrepreneur will work long hours for little reward they may feel more comfortable that an investment will be repaid, or that a person is 'worthy' of grant support. Hence, creating the right impression is equally important as the 'hard-work' itself.

At the same time, it is important to emphasise that too high expectations of social entrepreneurs might lead to over-commitment and a problematic work/life balance as well as prioritising organisational commitments over aspects of health, family and other aspects of 
social life (Dempsey and Sanders, 2010). If this pressure continues there is a danger that, in the long-term, social entrepreneurs might lose their passion and motivation. Our findings suggest, therefore, that social entrepreneurs who pursue a typical social business career path may be exposed to a punitive business environment that might disempower them. This work/life balance needs challenging in order not to discourage potential future social entrepreneurs from setting up social businesses.

\section{Access to social networks}

As suggested previously, access to well-resourced social networks, particularly through friends and family, were important in accessing finance during the early stages of social business growth. Participation in networks provides access to new customers and market information, and allows social entrepreneurs to exchange ideas, discuss the similar challenges they may encounter, and identify solutions to those challenges (Shaw and Carter, 2007). Variants of the old adage: "it's not what you know but who you know" was expressed in each of the focus groups. Similar to conventional entrepreneurs, 'successful' social entrepreneurs had used their connections to leverage resources that they require during the start-up and scale phases of growth. As one noted, "being inside of a network helped to develop the business and have access to market."

Many participants in our study talked about the importance of social networks as a route to external funding. 'Successful' social entrepreneurs had used personal relationships and connections to access, for example, informal loans, advice, new markets, find new staff and collaborate with other organisations. Frequently these forms of social networks had allowed a social business founder to access financial capital to 'prove their concept', or to directly attract investment from family and friends for start-up costs (the bank of dad again). Other 'successful' social entrepreneurs had been able to utilise social networks to boost their own profiles, or that of their social businesses. In turn this enhanced visibility and legitimacy was seen as making their social businesses attractive to funders outside of the original network.

For some social businesses, the combined networks of the founding team had provided considerable social capital ${ }^{4}$, which had been indirectly translated into soft loans, investments, and other resources (e.g. office space, pro-bono legal assistance or accounting

\footnotetext{
4. We conceptualsie social capital here as the sum of the resources, actual or virtual, that accrue to an individual or a group by virtue of possessing a durable network of more or less institutionalized relationships of mutual acquaintance and recognition' (Bourdieu and Wacquant 1992. P.119)
} 
services). Additionally, 'successful' social entrepreneurs talked of the importance of networks in findings the right people to recruit as first employees. Finally, social investors highlighted that they often provide the bridge to networks that link social entrepreneurs into new social networks. According to 'successful' social entrepreneurs, "having angels and investors at an early-stage that contribute to getting the right partners and people on board is one of the critical factors in success."

To some extent, social business support organisations, incubators and accelerators, such as the Hub, may be able to artificially replicate these social networks. These types of organisations were seen by hub members and by 'successful social entrepreneurs' as playing a potentially key role in supplying valuable connections to people and resources. One 'successful' social entrepreneur noted, 'being inside an umbrella organisation helped us access the market."

Notably, the type of social networks a social entrepreneur is embedded in was highlighted as particularly important. Hub members highlighted that "not getting the right network is the biggest blocker to growth." Many 'successful' social entrepreneurs in our study had family members and friends with significant financial resources. Hub members did not pick upon this, perhaps because as one Hub manager identified, this group was also skewed towards white, 'middle-class' males. This demographic group tends to have greater access to financial capital, often derived from networks that include wealthy and/or wellconnected people. Where a person is not connected to wealthy acquaintances either through family, or through looser social networks, they may often struggle to access finance in a world where the network's resources appear to be as important as the entrepreneur's resourcefulness. This has particular implications for the demographic make-up of 'successful social entrepreneurs' operating social businesses as (our admittedly exploratory study highlights) these may be drawn from the most privileged and / or well connected members of a group which already appears skewed towards white middle class males. We return to discuss the implications of this in the concluding section.

\section{Concluding Thoughts}

Our exploratory research set out to understand how nascent social businesses might access finance to achieve growth. The location for our study was a Social Business 'Hub' in London. The study indicated that funding options have a direct impact on the early-stage social business development and that lack of available funding leads to many social 
entrepreneurs being unable to introduce growth strategies. The study highlighted that social entrepreneurs with well-developed social networks are more likely to overcome growth challenges. For instance, in addition to promoting and enhancing activities of their social businesses, social networks can act as a tool that enables securing informal or preferable funding. Social entrepreneurs utilise therefore their governance and stakeholder networks to access and construct resources, and they deploy persuasive tactics to build legitimacy and financial sustainability. Some of these findings are not surprising and they echo conclusions of other related studies. However, research in social business development has largely neglected the social and cultural dynamics that embed start-ups. Our study shows a high importance of social connections indicating that relationships with high-status elites help to access financial resources and, as such, enhance business development. The right social connections enable, indeed, develop, competitive advantage. Entrepreneurs who are fortunate enough to have well-developed networks and skilfully present their dedication and commitment are more likely to succeed. In particular, a perception of commitment and talent, and not necessarily commitment and talent themselves, are useful in securing funding. Social networks and an ability to 'tell stories' of 'drive and talent', are therefore key attributes which help some social entrepreneurs to grow their ventures.

Although this ability to draw on existing resources and personal creativity should be celebrated, our study also highlights important issues. Access to resources appears equally uneven amongst social entrepreneurs as amongst mainstream entrepreneurs. Those without access to the 'bank of dad', or to privileged social networks or even the ability to 'selfpromote' are likely to miss out on potential financial support and, therefore, growth opportunities. We know that access to privileged social networks, and to the 'bank of dad' is determined by social class. Equally concerning, while participants in our study spoke of 'drive and talent', the emphasis was very much on the former and particularly the need to work long hours for low pay. While not highlighted by study participants, we suspect that those most able to work long hours for low pay (or even to tell a story of drive) are more likely to be men without child care responsibilities. This might suggest the demographic make up of social business owners would be skewed towards men from privileged backgrounds, a point hinted at by the Hub manager who highlighted their membership was skewed towards white middle class males. To some extent this gender bias is evidenced by other studies that show that while women are more likely than men to volunteer and work in third sector organisations, at the highest levels men outnumber women (Teasdale et al., 
2011). This vertical segregation by gender is most acute among for-profit social businesses similar to those in our study that are predominantly owned and managed by men.

To us there seems something slightly perverse about social businesses that allow profit distribution to owners and investors being owned by those from more privileged backgrounds, while those from poorer backgrounds are pushed to create not-for-profit selfhelp ventures. As the current support structures favours relatively privileged social entrepreneurs rather than encompassing and empowering disadvantaged groups, we might see a situation in which 'rich are getting richer' while social minority groups and those in the greatest need remain poor. This, in fact, works again the concept of social business that is often portrayed (possibly incorrectly) as a mechanism for addressing poverty through empowerment of disadvantaged and /or minority groups. This relates to complexities of empowerment (Skerratt and Steiner, 2013), problematic aspects of social capital whereby elites utilise networks for development and those without them do not enter the 'elite circles' (Bourdieu, 1986), and tensions between inclinations to create fairer systems and the lived practicalities. This is a particularly interesting finding for policymakers and social enterprise support organisations as it suggests that more needs to be done in relation to opening up access to support for social entrepreneurs from socially excluded backgrounds. In order to address this challenge, Hubs such as the one in our study might do more to attract women and those from more disadvantaged backgrounds, perhaps through offering reduced membership fees. However it may prove difficult to attract a more diverse membership if a culture of drive, commitment and long hours for little reward is in place. In order to facilitate the expansion of social businesses, it may be necessary to increase work satisfaction, health and wellbeing of social entrepreneurs. In addition, those interested in developing their career in social businesses need to be ensured that there is an appropriate support structure and that helping others does not have to be associated with underpaid jobs, stress, anxiety and selfsacrifice. Similarly some reflection upon the current fetishism for 'scale' and 'innovation' is necessary. Many of the participants in this study were comfortable operating as sole traders and did not want to risk their own financial futures (or those of employees) through seeking 'scale'. That does not mean they are not achieving social impact. It seems that there is a gap between community and political perspectives and there is a tension and ideological struggle between what the government wants from social enterprises and what social entrepreneurs want to achieve. This resonates with the point made my Parkinson and Howorth (2008) suggesting that while there is a lot of discussion in political arenas about social enterprises becoming more business-like with social entrepreneurship overtly positioned as the panacea 
to failure in market and state mechanism, many people involved in social enterprise focus on 'getting on with it' or 'getting the job done' (Pearce, 2003:68) at the local community level.

Policymakers, social business intermediaries and researchers would be well-advised to consider how to attract a wider variety of people to the social change 'industry', perhaps through promoting a culture of reasonable financial rewards and reasonable time commitments. The financial risk should be adequately shared between social entrepreneurs and social investors. While grants for social enterprises are frequently criticised as leading to inefficiency and dependency, mainstream funding options remain often too costly or not accessible for social businesses. A balanced approach supporting flexible and preferable loans for social businesses seem to offer more sustainable solution especially to early growth social businesses. It may also be possible for networks such as the Hub to require 'successful' social entrepreneurs emerging from their network to put something back into the sector. This might be achieved through taking an equity or quasi-equity stake in social businesses to fund the future growth of new social businesses.

Although we recognise that the findings of this exploratory study are limited by the methodological approach we adopted, some conclusions and recommendations support and extend discoveries of other studies. The applicability of our findings might have, therefore, a wider resonance and should be further tested and explored in future research. In particular, studies might usefully explore the demographic make up of different forms of social enterprise (for-profit and non-profit distributing) and on the impact of gender, education, age and social class upon access to social finance

\section{REFERENCES}

Aldrich, H. (1995), "Entrepreneurial strategies in new organisational populations", in Bull, I., Thomas, H. \& Willard, G. (Eds.) Entrepreneurship 2000, Oxford, Pergamon, pp. 91108.

Bachmann, M. (2014), "How the Hub found its centre." Stanford Social Innovation Review, (Winter).

Baker T and Nelson RE (2005) "Creating Something from Nothing: Resource Construction Through Entrepreneurial Bricolage." Administrative science quarterly, Vol. 50 No. 3, pp. 329-366.

Bedford, T. and Burgess, J. (2001), "Using focus groups in qualitative research", in Dwyer, C. and Limb, M. (Eds.) Qualitative research in geography, London, Arnold, pp. 121135. 
Bourdieu, P. (1986), "The Forms of Capital", in Richardson, J.G. (Ed.), Handbook of Theory and Research for the Sociology of Education, New York Greenwood.

Bourdieu, P. and Wacquant, L. (1992), An Invitation to Reflexive Sociology. University of Chicago Press, Chicago.

Carter, N.M., Gartner, W.B. and Reynolds, P. (1996), "Exploring start-up event sequences." Journal of Business Venturing, Vol. 11 No. 3, pp. 151-166.

Dacin, P, Dacin, M. and Matear, M. (2010), "Social entrepreneurship: why we don't need a new theory and how we move forward from here." Academy of Management Perspectives, Vol. 24, pp. 37-57.

Dempsey, S.E. and Sanders, M.L. (2010), "Meaningful work? Nonprofit marketization and work/life imbalance in popular autobiographies of social entrepreneurship." Organization, Vol. 17 No. 4, pp. 437-459.

Dey, P. and Teasdale, S. (2013), "Social enterprise and dis/identification: The politics of identity work in the English third sector." Administrative Theory \& Praxis, Vol. 35 No. 2, pp. 248-270.

Di Domenico, M., Haugh, H. and Tracey, P. (2010), "Social Bricolage: Theorizing Social Value Creation in Social Enterprises." Entrepreneurship Theory and Practice, Vol. 34 No. 4, pp. 681-703.

Doherty, B., Haugh, H. and Lyon, F. (2014), "Social enterprise as hybrid organizations: a review and research agenda." International Journal of Management Reviews, Vol. 16, pp. 417-436.

Glaser, B.G., Stauss, A.L. (1967) The Discovery of Grounded Theory, Chicago: Aldine.

Granter, W. (1985), "A conceptual framework for describing the phenomenon of new venture creation." Academy of Management Review, Vol. 10 No. 4, pp. 696-706.

Haugh, H. (2007), “Community-Led Social Venture Creation.” Entrepreneurship Theory and Practice, Vol. 31 No. 2, pp. 161-182.

Hockerts, K. (2006), "Entrepreneurial Opportunity in Social Purpose Business Ventures", in Mair, J., Robinson J. and Hockerts, K. (Eds.) Social Entrepreneurship. Basingstoke, Palgrave Macmillan.

Hynes, B. (2009), "Growing the social enterprise - issues and challenges." Social Enterprise Journal, Vol. 5 No. 2, pp. 114-125.

Jack, S.L. and Anderson, A.R. (2002), "The effects of embeddedness on the entrepreneurial process.” Journal of Business Venturing, Vol. 17 No. 1, pp. 467-488.

Janis, I. (1982), Groupthink: Psychology studies of policy decisions and fiascos, Boston: MA, Houghton-Mifflin.

Lévi-Strauss, C. (1966), The Savage Mind. The University of Chicago Press, Chicago. 
Lincoln, Y., Guba, E. (1985) Naturalistic Inquiry, Beverly Hills, CA: Sage Publications Inc.

Longhurst, R. (2003), "Semi-structured Interviews and Focus Groups", in: Clifford, N.J. and Valentine, G. (Eds.) Key methods in Geography, London: Sage, pp. 117-132.

Lounsbury, M. and Glynn, M.A. (2001), "Cultural entrepreneurship: stories, legitimacy, and the acquisition of resources.” Strategic Management Journal, Vol. 22, pp. 545-564.

Lyon, F. and Fernandez, H. (2012), "Strategies for scaling up social enterprise: lessons from early years providers.” Social Enterprise Journal, Vol. 8 No. 1, pp. 63-77.

McNeill, P., Chapman, S. (2005), Research Methods. Routledge, London.

Morgan, D.L. (2002) "Focus group interviewing", in Gubrium J.F. and Holstein J.A. (Eds.), Handbook of interviewing research: Context \& method, Thousand Oaks, Sage, pp. 141-159.

Nicholls, A. (2010), "The institutionalization of social investment: the interplay of investment logics and investor rationalities." Journal of Social Entrepreneurship, Vol. 1 No. 1, pp. $70-100$.

Parkinson, C. and Howorth, C. (2008), "The language of social entrepreneurs." Entrepreneurship and Regional Development, Vol. 20 No. 3, pp. 285-309.

Peirce, C. (1932), Collected Papers of Charles Sanders Peirce. Cambridge, MA, Belknap Press of Harvard University Press.

Porter, M. and Kramer, M. (2011), "Creating shared value. How to reinvent capitalism - and unleash the wave of innovation and growth." Harvard Business Review, (January/February) Vol. 17, pp. 63-70.

Schumpeter, J.A. (1934/1983), "The Theory of Economic Development: an Inquiry into Profits, Capital, Credit, Interest and the Business Cycle, Mass." Harvard Economic Series, Cambridge.

Scott, D. and Teasdale, S. (2012), "Whose failure? Learning from the financial collapse of a social enterprise in 'Steeltown'." Voluntary Sector Review, Vol. 3 No. 2, pp. 139-155.

Shaw, E. and Carter, S. (2007), "Social entrepreneurship theoretical antecedents and empirical analysis of entrepreneurial process and outcomes." Journal of Small Business and Enterprise Development, Vol. 14 No. 3, pp.418-34.

Skerratt, S. and Steiner, A. (2013), "Working with communities-of-place: complexities of empowerment.” Local Economy, Vol. 28 No. 3, pp. 320-338.

Steiner, A. and Cleary, J. (2014), "What are the features of resilient businesses? Exploring the perception of rural entrepreneurs." Journal of Rural Community and Development, Vol. 9 No. 3, pp. 1-20.

Steinerowska-Streb, I. and Steiner, A. (2014), "An Analysis of External Finance Availability on SMEs' Decision Making." Thunderbird International Business Review, Vol. 56 No. 4, pp. 373-386. 
Steinerowski, A., Jack, S. and Farmer, J. (2008), "Who are the social entrepreneurs and what do they actually do?" Frontiers of Entrepreneurship Research, Vol. 28 No. 21, pp. 693-708.

Stewart, D.W., Shamdasani, P.N. and Rook, D.W. (2007), Focus groups: theory and practice $2^{\text {nd }}$ ed., Sage, Thousand Oaks, CA.

Sunley, P. and Pinch, S. (2012), "Financing social enterprise: social bricolage or evolutionary entrepreneurialism?” Social Enterprise Journal, Vol. 8 No.2, pp. 108-122.

Taylor, S. J., \& Bogdan, R. (1984). Introduction to Qualitative Research Methods: The Search for Meanings, New York: Wiley.

Teasdale, S. (2010), "Exploring the multifaceted nature of social enterprise: impression management as (social) entrepreneurial behaviour" Voluntary Sector Review, Vol. 1 No. 3, pp. 271-92.

Teasdale, S. (2012a), "What's in a name? Making sense of social enterprise discourses." Public Policy \& Administration, Vol. 27 No. 2, pp. 99-115.

Teasdale, S. (2012b), "Negotiating tensions: how do social enterprises in the homelessness field balance social and commercial considerations?" Housing Studies, Vol. 27 No. 4, pp. 514-532.

Teasdale, S., Lyon, F. and Baldock, R. (2013), "Playing with numbers: a methodological critique of the social enterprise growth myth." Journal of Social Entrepreneurship, Vol. 4 No. 2, pp. 113-131.

Teasdale, S., McKay, S., Phillimore, J. and Teasdale, N. (2011), "Exploring gender and social entrepreneurship: women's leadership, employment and participation in the third sector and social enterprises." Voluntary Sector Review, Vol. 2 No. 1, pp. 57-76.

Toivonen, T. and Friederici, N. (2015), "Time to Define What a "Hub" Really Is." Stanford Social Innovation Review, (February).

Vickers, I. and Lyon, F. (2012), "Beyond green niches? Growth strategies of environmentally-motivated social." International Small Business Journal, Vol. 32 No. 4, pp. 449-470.

Wiles, R., Crow, G., Heath, S. and Charles, V. (2006), Anonymity and Confidentiality, Paper presented at the ESRC Research Methods Festival, University of Oxford, available at: http://eprints.ncrm.ac.uk/423/1/0206 anonymity\%2520and\%2520confidentiality.pdf (18 December 2014).

Wilson, F. and Post, J. (2013), "Business models for people, planet (\& profits): exploring the phenomena of social business, a market based approach to social value creation." Small Business Economics, Vol. 40 No. 3, pp. 715-737.

Yunus, M., Moingeon, B. and Lehmann-Ortega, L. (2010), "Building social business models: lessons from the Grameen experience." Long range planning, Vol. 43 No. 2, pp. 308325. 